Карданова Ирина Викторовна

старший преподаватель кафедры государственно-правовых дисциплин Северо-Кавказского филиала Российского государственного университета правосудия

\section{К ВОПРОСУ ОБ ОПРЕДЕЛЕНИИ ПОНЯТИЯ «МНОГОДЕТНАЯ СЕМЬЯ» В ПРАВЕ СОЦИАЛЬНОГО ОБЕСПЕЧЕНИЯ}

Аннотация:

В статье проводится анализ различных точек зрения по вопросу определения понятий "семья", «многодетная семья», «многодетный родитель», которые лежат в основе социального обеспечения семей с детьми и направлены на решение демографической проблемы в России. Рассматриваются различные мнения ученых смежных отраслей права, выявляются теоретические проблемы, предлагаются авторская формулировка исследуемых понятий и пути решения указанных проблем в теории права социального обеспечения. Сделан вывод, что необходимо принять федеральный закон "О государственной поддержке многодетных семей в Российской Федерации», который позволит на федеральном уровне систематизировать и определить основные понятия, которыми оперирует законодательство субъектов РФ, а также в открытом перечне перечислить меры государственной поддержки, предоставляемые семьям с детьми со стороны как Российской Федерации, так и ее субъектов.

\section{Ключевые слова:}

социальное обеспечение, демографический кризис, многодетная семья, многодетные родители, меры государственной поддержки, законодательство субъектов Российской Федерации.

\section{Kardanova Irina Viktorovna}

Senior Lecturer, State Law Department, North Caucasus branch of Russian State University of Justice

\section{CONCERNING THE DEFINITION OF A LARGE FAMILY IN SOCIAL SECURITY LAW}

Summary:

The article analyses the various viewpoints on the concepts of family, large family, parent of a large family that underlie social security of families with children and address the population problem in Russia. The paper discusses the several opinions of scientists focused on the adjacent branches of law, reveals the theoretical problems, presents the author's definition of the terms under review, and offers the solutions to these problems in the theory of social security law. The author concludes that it is necessary to adopt the Federal Law on State Support for Large Families in the Russian Federation which allows one to classify at the federal level and identify the main concepts applied in the legislation of the constituent entities of the Russian Federation. Besides, there is a need to present the non-exhaustive list of government support measures provided for families with children at national and regional levels.

В апреле 2011 г. Берлинский институт народонаселения и развития опубликовал доклад «Исчезающая мировая держава» [1], который содержит масштабный анализ демографических процессов, происходящих в настоящее время в России и странах бывшего СССР. Главный вывод исследования отражен в названии доклада.

По данным Росстата, в первом полугодии 2017 г. по сравнению с аналогичным периодом 2016 г. в России отмечалось снижение числа родившихся (в 84 субъектах Российской Федерации) и числа умерших (в 73 субъектах) [2]. Другими словами, возобновилась тенденция естественной убыли населения, которая устойчиво наблюдалась с 1993 по 2008 г. Выходу из демографрического кризиса в России должна способствовать государственная поддержка многодетных семей, которые нуждаются в повышенном внимании со стороны федеральной и региональной властей.

Значительный вклад в разработку указанной проблемы призвана внести юридическая наука, поскольку принципиальные социально-экономические решения, влияющие на демографические процессы, осуществляются правовыми средствами. Это и определяет необходимость проведения специальных правовых исследований в данной области.

Согласно Конституции РФ семья - это конституционно-правовая категория, основанная на браке (юридически оформленном, добровольном союзе мужчины и женщины), порождающая взаимные личные и имущественные права и обязанности, направленные на создание семьи, рождение и воспитание детей (ст. $7,38,72)$ [3]. Единого понятия «семья» в современной науке не существует, нет и четкого юридического определения семьи. В разных социальных сфрерах она определяется по-своему. 
А.И. Пьянов отмечал, что социальное явление вообще всегда тяжело поддается дефинитивной характеристике [4, с. 46]. Семья - это сложное социальное образование. Специалисты различных отраслей науки, подчеркивая роль семьи как первичной социальной ячейки общества, определяют это понятие в зависимости от того, в каком аспекте им приходится рассматривать эту человеческую общность (например, как конкретную систему взаимоотношений между супругами, родителями и детьми; малую группу, члены которой связаны брачными или родственными отношениями, общностью быта и взаимной моральной ответственностью; социальную необходимость, которая обусловлена потребностью общества в физическом и духовном воспроизводстве населения [5]).

Правоведы прошлого столетия определяли семью как круг людей, связанных правами и обязанностями, вытекающими из брака или родства [6, с. 43], т. е. как человеческую группу, связанную правами и обязанностями, предусмотренными законодательством о браке и семье [7, с. 80]. По мнению А.М. Беляковой и Е.М. Ворожейкина, необходимо выработать определение, пригодное для всех отраслей права: «...Не может быть нескольких определений понятий семьи в праве для разных отраслей, оно должно быть единым, хотя и в понятии члена семьи каждой отраслью отражается присущая ей специфика» [8, с. 33].

Проведя анализ семейного, гражданского права и права социального обеспечения, Е.Ф. Чернышева пришла к выводу о том, что подход к указанному понятию различен не только в разных отраслях советского права, даже в отдельных нормативных актах в пределах одной отрасли содержание понятия «член семьи» неодинаково [9].

Попробуем и мы ответить на вопросы, можно ли выработать единое определение понятия «семья» и есть ли в этом необходимость на современном этапе.

Концепция государственной семейной политики в Российской Федерации на период до 2025 г. [10] к традиционным семейным ценностям относит ценности брака, понимаемого как союз мужчины и женщины, основанный на государственной регистрации в органах записи актов гражданского состояния, заключаемый в целях создания семьи, рождения и (или) совместного воспитания детей, основанный на заботе и уважении друг к другу, к детям и родителям, характеризующийся добровольностью, устойчивостью и совместным бытом, связанный с взаимным стремлением супругов и всех членов семьи к его сохранению. Несмотря на то что в упомянутой Концепции речь идет не о семье, а о браке, сказанное в ней имеет значение и для определения семьи, поскольку в семейные ценности включены зарегистрированные браки и подчеркивается значение семьи для рождения и воспитания детей.

Термин «семья» используется в различных отраслях права. Трудовое право и право социального обеспечения чаще всего оперируют понятием «семья с детьми», поскольку именно таким семьям адресованы предусмотренные законодательством меры государственной поддержки. Но и в этом случае мы не найдем определений, пригодных для всех случаев поддержки таких семей.

В законодательстве РФ о социальном обеспечении, казалось бы, можно встретить трактовку (от узкой до весьма широкой) этого понятия. Однако все меры социального обеспечения, предусмотренные соответствующим законодательством, как правило, учитывают не всю семью в целом как единую категорию, а лишь совокупность весьма определенных членов семьи.

Так, при определении права на пособия, устанавливаемые в субъектах РФ, из всех членов семьи учитываются только совместно проживающие родители (усыновители) и их несовершеннолетние дети; одинокий родитель (усыновитель) и проживающие совместно с ним его несовершеннолетние дети. Если совместно проживающие родители имеют общего ребенка, то в состав семьи включаются проживающие в данной семье дети каждого из родителей, в том числе пасынки и падчерицы. При этом не принимается во внимание факт ведения общего хозяйства.

В соответствии с федеральным законом о прожиточном минимуме при определении права на государственную социальную помощь круг учитываемых членов семьи расширяется, поскольку при определении дохода семьи помимо родителей и детей учитываются также лица, не только связанные родством и (или) свойством, но и совместно проживающие и ведущие совместное хозяйство.

В пенсионном законодательстве семья выглядит по-иному. При назначении страховой пенсии по случаю потери кормильца принимаются во внимание не все члены семьи умершего кормильца, а только нетрудоспособные и к тому же состоявшие на его иждивении. В ч. 2 ст. 10 федерального закона «О страховых пенсиях» (далее - Закон о страховых пенсиях) [11] дан достаточно широкий перечень нетрудоспособных членов семьи, которым может быть назначена такая пенсия. Для назначения пенсии не имеет значения ни совместное проживание членов семьи, ни ведение совместного хозяйства.

Изложенное подтверждает, что на современном этапе вряд ли возможно добиться единого определения понятия «семья», подходящего для использования при предоставлении всех видов социального обеспечения. Более того, для различных институтов права социального обеспечения необходимо сохранить разделение семей по их составу, уточнив понятие многодетной семьи 
для предоставления им мер государственной поддержки. В связи с этим возникает необходимость уяснить, что понимается под термином «многодетная семья» в праве социального обеспечения, и сорормулировать авторское определение.

По количеству воспитывающихся в семьях детей обычно различаются малодетные семьи (с одним-двумя детьми), среднедетные (с тремя-четырьмя детьми) и многодетные (с пятью и более детьми). Такая классификация семей имеет в виду демографический критерий обеспечения замещения поколения родителей поколением детей.

В рамках исследовательского проекта «Таганрог», начало которого относилось ко второй половине 1960-х гг., а окончание - к 2000 г. [12, с. 77], многодетными признавались семьи с четырьмя и более детьми. Такое же понятие многодетной семьи использовалось и при выплате пособий многодетным матерям в советский период.

В настоящее время Указом Президента РФ от 5 мая 1992 г. № 431 «О мерах по социальной поддержке многодетных семей» [13] установлено, что субъекты РФ вправе самостоятельно определять критерии многодетной семьи с учетом национальных, культурных, социально-экономических и демографических особенностей конкретного региона.

Как показала практика, каждый субъект РФ определяет социальный статус такой семьи исходя не только из реальных масштабов этого явления в регионе, но и учитывая свои бюджетные возможности, поскольку признание семьи многодетной влечет установление ей льготного статуса и предоставление мер государственной поддержки. Для целей государственной поддержки в современной России многодетной, как правило, считается семья, в которой трое и более детей в возрасте до 16 лет, а также до 18 лет, если дети обучаются в образовательных организациях, реализующих общеобразовательные программы. Варианты бывают лишь в отношении возраста детей, учитываемых при оказании государственной поддержки (например, в законе Краснодарского края «О социальной поддержке многодетных семей в Краснодарском крае» [14] речь идет о детях, не достигших 23 лет).

В соответствии со ст. 2 Социального кодекса Санкт-Петербурга [15] многодетной считается семья (неполная семья), имеющая в своем составе трех и более детей (в том числе усыновленных, находящихся под опекой (попечительством) в возрасте до 18 лет.

Закон города Москвы «О социальной поддержке семей с детьми в городе Москве» [16] к многодетной относит семью, в которой родились и (или) воспитываются трое и более детей (в том числе усыновленные, а также пасынки и падчерицы) до достижения младшим из них возраста 16 лет (учащимся в образовательном учреждении, реализующем общеобразовательные программы, - 18 лет).

Предлагаем сорормулировать определение следующим образом: «В целях предоставления государственной поддержки многодетная семья - это совместно проживающие родители (усыновители), которые воспитывают четырех и более детей (родных, усыновленных) в возрасте до 18 лет (учащихся по очной форме обучения - до окончания ими учебного заведения, но не старше 23 лет). Если указанное количество детей воспитывает одинокий родитель (одинокий усыновитель), то многодетной следует считать семью при наличии трех таких детей.

В целях пенсионного обеспечения многодетным считать одного из родителей, воспитавшего пять и более детей до 8-летнего возраста, если второй родитель не воспользовался правом на досрочное пенсионное обеспечение в отношении этих детей».

Большинство проблем гендерного равноправия традиционно сосредоточены в трудовом праве и праве социального обеспечения. Выстраивая предпосылки их решения, А.М. Лушников и М.В. Лушникова отмечают, что признак пола как таковой следует практически исключить в качестве основания дифференциации - «работники» должны делиться на «мужчин» и «женщин», когда они становятся «лицами с семейными обязанностями», однако и «полное игнорирование половой специфики ведет в тот же тупик, что и выдвижение ее в качестве основной» [17, с. 17].

Считаем необходимым закрепить законодательно обобщающее понятие «одинокий родитель», а для случаев более широкой государственной поддержки - понятие «многодетный родитель», предусмотрев единый подход к указанному вопросу на всей территории РФ.

Важно на федеральном уровне систематизировать и определить понятия «многодетная семья», «многодетные родители», «государственная поддержка», «меры поддержки» и др., которыми оперирует законодательство субъектов РФ. Правовое определение понятия многодетной семьи должно быть закреплено в федеральном законе «О государственной поддержке многодетных семей в Российской Федерации».

\section{Ссылки:}

1. Sievert S., Sacharow S., Klingholz R. Die schrumpfende Weltmacht. Die demografische Zukunft Russlands und der anderen post-sowjetischen Staaten. Berlin, 2011. $148 \mathrm{~S}$. 
2. Социально-экономическое положение России. 2017 г. [Электронный ресурc]. URL: http://www.gks.ru/wps/wcm/connect/rosstat_main/rosstat/ru/statistics/publications/catalog/doc_1140086922125 (дата обращения: 17.09.2017).

3. Конституция Российской Федерации : принята всенар. голосованием 12 дек. 1993 г. : с учетом поправок, внес. законами РФ о поправках к Конституции РФ от 30 дек. 2008 г. № 6-ФКЗ, от 30 дек. 2008 г. № 7-ФКЗ, от 5 февр. 2014 г. № 2-ФКЗ от 21 июля 2014 г. № 11-ФКЗ // Собрание законодательства Российской Федерации (СЗ РФ). 2014. № 31. Ст. 4398.

4. См.: Пьянов А.И. Социальный институт семьи в условиях трансформации общественного строя в России : монография. Ставрополь, 2006. 313 с.

5. См.: Психология семейных отношений с основами семейного консультирования / Е.И. Артамонова, Е.В. Екжанова, Е.В. Зырянова; под ред. Е.Г. Силяевой. М., 2002. 192 с.

6. Советское семейное право : учебник / А.М. Белякова, В.А. Рясенцев, В.Ф. Яковлев ; под ред. В.А. Рясенцева. М., 1982. $256 \mathrm{C}$.

7. См.: Нечаева А.М. Брак, семья, закон / отв. ред. В.А. Рясенцев. М., 1984. 145 с.

8. См.: Белякова А.М., Ворожейкин Е.М. Советское семейное право. М., 1974. 303 с. ; Ворожейкин Е.М. Правовые основы брака и семьи. М., 1969. 160 с.

9. См.: Чернышева Е.Ф. Понятие семьи в праве социального обеспечения // Правоведение. 1980. № 1. С. 59-63.

10. Об утверждении Концепции государственной семейной политики в Российской Федерации на период до 2025 г. : распоряжение Правительства РФ от 25 авг. 2014 г. № 1618-р // С3 РФ. 2014. № 35. Ст. 4811.

11. О страховых пенсиях : федер. закон от 28 дек. 2013 г. № 400-ФЗ : ред. от 19 дек. 2016 г. : с изм. и доп., вступ. в силу с 1 янв. 2017 г. // Там же. 2013. № 52 (ч. І). Ст. 6965.

12. Женщина, мужчина, семья в России: последняя треть XX века. Проект «Таганрог» / под ред. Н.М. Римашевской. М., 2001. $320 \mathrm{c}$

13. О мерах по социальной поддержке многодетных семей [Электронный ресурс] : указ Президента РФ от 5 мая 1992 г. № 431. URL: http://www.kremlin.ru/acts/bank/1254 (дата обращения: 11.10.2017).

14. О социальной поддержке многодетных семей в Краснодарском крае : закон Краснод. края от 22 февр. 2005 г. № 836 КЗ // Информационный бюллетень Законодательного собрания Краснодарского края. 2005. № 27 (98). 30 марта.

15. Социальный кодекс Санкт-Петербурга : закон Санкт-Петербурга от 22 нояб. 2011 г. № 728-132 : ред. от 20 июня 2017 г. : принят Законодательным собранием Санкт-Петербурга 9 нояб. 2011 г. // Информационный бюллетень Администрации Санкт-Петербурга. 2011. № 46.

16. О социальной поддержке семей с детьми в городе Москве : закон города Москвы от 23 нояб. 2005 г. № 60 // Вестник Мэра и Правительства Москвы. 2005. № 70.

17. См.: Гендерное равенство в семье и труде: заметки юристов: монография / Н.Н. Тарусина, А.М. Лушников, М.В. Лушникова, Е.А. Исаева. М., 2006. С. 87-88 ; Тарусина Н.Н. Гендерная экспертиза российского законодательства. Ярославль, 2012. 44 с.

\section{References:}

Artamonova, EI, Ekzhanova, EV, Zyryanova, EV \& Silyayeva, EG (ed.) 2002, Psychology of family relations with the basics of family counseling, Moscow, 192 p., (in Russian).

Belyakova, AM, Ryasentsev, VA \& Yakovlev, VF (eds.) 1982, Soviet family law, textbook, Moscow, 256 p., (in Russian).

Belyakova, AM \& Vorozheikin, EM 1974, Soviet family law, Moscow, 303 p., (in Russian).

Chernysheva, EF 1980, 'The concept of family in the law of social security', Pravovedeniye, no. 1, pp. 59-63, (in Russian).

'Law No. 60 on the Social Support of Families with Children in the City of Moscow as of 23 November 2005' 2005, Vestnik Mera i Pravitel'stva Moskvy, no. 70, (in Russian).

'Law No. 728-132 The Social Code of St. Petersburg as of November 22, 2011 amended on June 20, 2017 adopted by the Legislative Assembly of St. Petersburg on November 09, 2011' 2011, Informatsionnyy byulleten' Administratsii Sankt-Peterburga, no. 46, (in Russian).

'Law No. 836-KZ on the Social Support of Large Families in the Krasnodar Territory as of February 22, 2005', Informatsionnyy byulleten' Zakonodatel'nogo sobraniya Krasnodarskogo kraya, no. 27 (98), March 30, (in Russian).

Nechaev, AM \& Ryasentsev, VA (eds.) 1984, Marriage, family, law, Moscow, 145 p., (in Russian).

Pyanov, Al 2006, Social institution of the family in the context of the transformation of the social order in Russia, monograph, Stavropol, 313 p., (in Russian).

Rimashevskaya, NM (ed.) 2001, A woman, a man, a family in Russia: the last third of the 20th century. Taganrog Project, Moscow, 320 p., (in Russian).

Sievert, S, Sacharow, S \& Klingholz, R 2011, Die schrumpfende Weltmacht. Die demografische Zukunft Russlands und der anderen post-sowjetischen Staaten, Berlin, $148 \mathrm{~S}$., (in German).

Tarusina, NN 2012, Gender expertise of the Russian legislation, Yaroslavl, 44 p., (in Russian).

Tarusina, NN, Lushnikov, AM, Lushnikova, MV \& Isaeva, EA 2006, Gender equality in family and work: notes by lawyers, monograph, Moscow, pp. 87-88, Moscow, (in Russian).

Vorozheykin, EM 1969, Legal basis of marriage and family, Moscow, $160 \mathrm{p}$ 